\title{
Hur påverkas psykisk hälsa av arbete och familjeliv?
}

\section{ULLA BJÖRNBERG}

Kvinnors psykiska hälsa och välbefinnande är sämre än männens. Detta sammanhänger med arbetsfördelningen $i$ hemmet och med villkor i arbetslivet. Att leva i familjer där många konflikter förekommer visar påtagliga samband med negativ upplevelse av hemansvar och med psykiskt välbefinnande.

Kvinnors psykiska hälsa har under senare tid uppmärksammats allt mer. En bakgrund till det ökade intresset är den höga andelen stressrelaterade sjukdomar hos kvinnor. Visserligen är kvinnor generellt inte sjukare än män mätt utifrån dödlighet och risken att drabbas av svåra sjukdomar som hjärtsjukdomar och cancer (Holm, 1990). Men kvinnor har fler symptom, främst psykiska t.ex. nervösa besvär, huvudvärk, trötthet, depressioner, sömnstörningar (Lundberg, 1990). Kvinnor söker läkare oftare än män och har fler sjukdagar.

Förutom att kvinnor har sämre välbefinnande är det också kvinnor som i ökad utsträckning väljer att bryta upp familjen. Skilsmässor och separationer ökar och kvinnor tar initiativ till skilsmässor i större utsträckning

Ulla Björnberg är docent i sociologi vid Göteborgs Universitet. Hon forskar om modernt familjeliv med särskild tonvikt på familjepolitikens och förvärvsarbetets betydelse i familjers vardagsliv. än män (Wadsby och Svedin, 1994; KochNielsen m.fl. 1987).

Mår kvinnor sämre än män, eller är det mer accepterat för kvinnor att tala om sina problem och att rapportera om dem i undersökningar om psykisk hälsa och välbefinnande? Ställer kvinnor större krav på psykisk hälsa och välbefinnande än män? Eller är det helt enkelt så att kvinnors lägre välbefinnande är sämre därför att deras livsvillkor är mer pressade än mäns?

I en europeisk jämförelse förvärvsarbetar svenska kvinnor med barn under 10 år i betydligt högre utsträckning än kvinnor i andra länder. 87 procent av svenska kvinnor med barn < 10 år förvärvsarbetar mot mellan 5060 procent i länder inom EU (Björnberg, 1994).

Svenska kvinnor arbetar deltid i större utsträckning, men heltidsarbetet har ökat under 80-talet i Sverige, vilket har förklarats bl.a. vara en effekt av skattereformen 1983, 
och den höga efterfrågan på arbetskraft under 80-talet (Sundström, 1993).

Kvinnor generellt har stressiga arbeten i betydligt högre utsträckning än män. Under det senaste decenniet har arbetsvillkoren för kvinnor försämrats så att andelen med mycket stressiga arbeten har ökat (Lundberg \& Fritzell, 1993). Med «mycket stressiga arbeten" avses att arbetet innebär psykologiska krav i kombination med att autonomin $i$ arbetet är låg (dvs. möjligheten att själv bestämma över arbetet). Denna typ av jobb har ökat under 80-talet, särskilt för kvinnor med arbeten som innebär kvalifikation på medelnivå (Szulkin \& Tåhlin, 1993).

Det finns således flera faktorer knutna till kvinnors arbetssituation som skulle kunna förklara ökad psykisk ohälsa bland kvinnor.

Villkoren för familjeliv och psykisk hälsa hos kvinnor och män har emellertid inte bara med arbetslivet att göra. Kvinnor har större ansvar för hem och barn och lägger ned nästan dubbelt så mycket tid som män på dagligt arbete i hemmet (Rydenstam, 1993). Förutsättningar för familjeliv förändras också i takt med intimsfärens ökade betydelse (Giddens, 1992). Kvinnor och män har olika måttstockar för vad som är goda familjerelationer och hur ett bra samliv skall se ut. Det finns därför anledning att studera villkor i familjelivet och hur dessa upplevs av kvinnor och män som självständiga faktorer i samband med analyser av psykiskt välbefinnande.

\section{Forskning om könsskillnader och hälsa}

I undersökningar om förhållandet mellan arbetsvillkor och psykisk hälsa framgår att kvinnor och män påverkas på samma sätt av liknande arbetsvillkor. Tex. blir kvinnor och män lika påverkade av kombinationen att sakna inflytande över sin arbetssituation och höga krav på prestation (Karasek och Theorell, 1990; Lundberg, 1990). I diskussionerna om kvinnornas sämre välbefinnande framkommer ofta att deras hälsotillstånd måste ses i ett större perspektiv och relateras till både deras arbets- och familjesituation (Moen,1989; Hall, 1990). Forskningen om betydelsen av faktorer i hemmet och dessas samband med psykisk hälsa hos kvinnor och män visar emellertid också att familjeförhållanden har olika betydelse för könen.

Phyllis Moen undersökte förvärvsarbetande småbarnsföräldrars fysiska och psykiska hälsa med empiriska data från Levnadsnivåundersökningen 1974 och 1981 . Hennes resultat visar att mödrarna hade högre benägenhet att vara trötta och ha lägre psykiskt välbefinnande än fäderna. Särskilt utsatta var ensamstående mödrar med skolbarn, vilket tolkas bero på att en partner kan bidra till att dämpa både psykologisk press och fysisk trötthet. Hennes resultat visar också att mödrar från arbetarklassen var mer utsatta för psykologisk press än mödrar från andra klasser. Vidare att fäder i högt kvalificerade yrkeskategorier är mest utsatta för psykisk press.

Moens analyser visar att deltidsarbete hade en dämpande effekt på mödrarnas trötthet, men att arbetstid inte hade någon betydelse vad gäller psykologiskt välbefinnande. För män fanns inga sådana samband. Arbetsvillkoren hade betydelse för daglig trötthet för både kvinnor och män. Både fysiskt krävande och psykiskt pressande arbeten påverkade både daglig trötthet och det psykiska välbefinnandet.

Olle Lundberg har funnit att skillnader 
mellan könen i psykisk och fysisk hälsa har starka samband med graden av ansvar för hushållsarbete. Han analyserade den sammantagna effekten av att kvinnor tar ett större ansvar för hushållsarbetet och deras integration i samhällslivet, dvs. politisk delaktighet och engagemang i samhälleliga organisationer. Graden av ansvar för hemmet mättes som andelen utfört hushållsarbete och graden av deltagande i samhällsliv utanför hemmet mättes utifrån antalet roller som upprätthålls. Analysen visade att män hade ett betydligt högre samhällsengagemang och utförde betydligt mindre hushållsarbete än kvinnor. Skillnader i psykisk och fysisk ohälsa mellan kvinnor och män är konsekvenser av dels kvinnors större ansvar för hem och familj dels kvinnors lägre grad av socialt deltagande i samhället. Båda faktorer i kombination förklarar varför kvinnor har högre psykisk och fysisk ohälsa än män, menar Lundberg (Lundberg 1990).

Ellen Hall studerade effekten av arbetsvillkor resp. graden av ansvar för hushållsarbete på förvärvsarbetande kvinnors upplevelse av stress i hemmet och psykisk hälsa. Stress i hemmet (hemstress) mättes som upplevelse av hemarbetet som mödosamt eller ej. Arbetsvillkor mättes utifrån data om upplevelse av stress i arbetet, graden av. kontroll över arbetet, socialt stöd i arbetet samt fysiska krav. Hon fann att mäns och kvinnors hemstress påverkades av olika faktorer. För kvinnor fanns signifikanta samband mellan hemstress och psykiska krav i arbetet samt arbetstid. För män ökade hemstress av att de utförde de mesta arbetsuppgifterna i hemmet, dvs. de fall där deras situation liknar den som majoriteten av kvinnorna lever i. För kvinnor fanns det i undersökningen signifi- kanta samband mellan hemstress och psykosomatiska symptom (Hall, 1990). Ensamstående män hade högre sannolikhet för att känna hemstress.

Dessa studier ger stöd för behovet av att studera interaktionen mellan förhållanden $i$ arbetet och hemarbete vid analyser av psykisk hälsa hos kvinnor och män.

\section{Syfte och uppläggning}

I denna artikel skall jag presentera några resultat som behandlar förhållandet mellan psykiskt välbefinnande och upplevelse av arbetssituationen i familjen mot bakgrund av arbetsförhållanden och familjeförhållanden. Jag vill rikta uppmärksamheten mot själva arbetet i familjen och hur man upplever detta dels mot bakgrund av hur arbetsvillkoren ser ut men också familjesituationen som sådan. Resultaten bygger på en empirisk studie av förvärvsarbetande småbarnsföräldrar. Studien som helhet syftar till att studera samverkan mellan familjeliv, familjepolitik och förvärvsarbete. Intervjuer med småbarnsföräldrar genomfördes hösten 1992. Urvalet baserades på femåringar, deras mödrar och de män som fanns med i hushållet, vilka till 90 procent var barnens biologiska fäder. Intervjuerna genomfördes separat med män och kvinnor i familjerna. Av de valda hushållen hade 60 procent barn under fem år, vilket således betyder att de intervjuade familjerna var småbarnsfamiljer. 670 individer intervjuades, däribland 215 män och 146 ensamstående mödrar.

I artikeln presenteras preliminära resultat utifrån enkel deskriptiv statistisk bearbetning. Följande frågeställningar skall belysas: - Hur påverkas kvinnors och mäns psy- 
kiska välbefinnande av deras 1) upplevelse av arbetsvillkoren i förvärvsarbetet 2) mängden förvärvsarbete (arbetstid)?

- Hur påverkas upplevelsen av hemansvar bland kvinnor och män av 1) arbetsvillkor 2) mängden förvärvsarbete samt 3) familjesituation?

- Hur påverkas kvinnors och mäns psykis$k$ a välbefinnande av upplevelsen av hemansvar och familjesituation?

Familjesituationen belyses utifrån följande indikatorer:

antal barn; konflikter i familjen ${ }^{1}$

Upplevelsen av hemansvar har belysts med följande indikatorer:

Hur man känner sig när man kommer hem från jobbet; Hur man upplever arbetet i familjen; Hur väl man anser att man klarar att balansera arbete och familj.

Artikeln har disponerats så att inledningsvis presenteras bakgrundsinformation beträffande förvärvsarbetet för kvinnor och män arbetstider, upplevelse av arbetsvillkor samt bedömning av psykiskt välbefinnande.

I nästa avsnitt presenteras resultat rörande upplevelse av hemansvar i relation till dels situationen på arbetet dels familjesituationen.

1 Konflikter i familjen är ett index som bygger på svaren på följande frågor: "Händer det att hushållsarbetet eller arbetet med barnen leder till konflikter mellan dig och din partner? Händer det att frågor om barnuppfostran leder till konflikter mellan dig och din partner? Händer det att frågor om hur era inkomster skall användas leder till konflikter mellan dig och din partner?
Resultaten redovisas för olika yrkesgrupper.

\section{Arbetstid, arbetsvillkor och psykisk hälsa}

Resultaten från undersökningen visar att jämförelsevis många kvinnor med små barn arbetar heltid. Av mödrarna arbetade 43 procent heltid (35 timmar i veckan eller mer, vilket numer räknas som heltid) och 46 procent arbetade deltid, dvs. 20-34 timmar per vecka. Enligt en undersökning från 1984 för mödrar med barn 0-5 år arbetade 20 procent heltid och 42 procent deltid (Hushållens ekonomiska levnadsförhållanden - HUS-undersökningen, opublicerad tabell)2 ${ }^{2}$. Jämförelsen tyder på att även mödrar med små barn har ökat sin arbetstid.

\section{Upplevelse av arbetsvillkor}

En jämförelse mellan kvinnor och män totalt i min undersökning visar att upplevelsen av arbetsvillkoren fördelar sig ganska likt mellan könen. Drygt 30 procent av männen och 27 procent av kvinnorna bedömer arbetsvillkoren som betungande i ett samlat mått ${ }^{3}$ (se tabell 1). Könsskillnaderna är små också för varje enskild indikator inom måttet, med undantag för risker i jobbet. Nästan dubbelt

2 Undersökningen om hushållens ekonomiska levnadsförhållanden under ledning av professor Anders Klevmarken, Nationalekonomiska Institutionen, Göteborgs Universitet

3 Arbetsvillkor har mätts som ett summationsindex. Detta bygger på subjektiv rangordning av arbetsvillkor enligt en fempunktsskala med följande indikatorer: Stressigt-Lugnt; Fysiskt tungt-Lätt; Ohygieniskt (Smutsigt)-Rent; Monotont-Stimulerande; Riskfullt-Säkert; Otrygg anställning-Trygg anställning. 


\section{Tabell 1}

Samlad bedömning av arbetsvillkor bland gifta/samboende kvinnor och män. Procentandelar.

\begin{tabular}{lrr} 
& Män & Kvinnor \\
\cline { 2 - 3 } Betungande & 31 & 27 \\
Något betungande & 38 & 44 \\
Ej betungande & 31 & 30 \\
\hline Totalt & 100 & 100 \\
$N$ & 199 & 349 \\
\hline
\end{tabular}

så många män (28 procent) som kvinnor anser att de har riskfyllda jobb.

Jämförelsen mellan kvinnor och män på indexet för arbetsvillkor visar att upplevelserna av arbetsvillkoren skiljer sig ganska litet när de har samma klasstillhörighet. ${ }^{4}$

Skillnaderna i upplevelser av arbetsvillkor skiljer sig avsevärt vid jämförelser mellan olika klasser. Totalt sett bedömer arbetare sina arbetsvillkor som sämre än tjänstemän på mellan- och hög nivå.

Bland arbetarna var den största gruppen av kvinnorna - 49 procent - tjänstearbetare. Bland männen var den största gruppen varuproducerande arbetare (33 procent).

Mer än 40 procent av de tillfrågade anser att deras arbetssituation är stressig. Upplevelse av stress i arbetet är särskilt frekvent bland tjänstemän på mellan- och på hög nivå. Bland kvinnorna upplever 57 procent av tjänstemän på mellannivå och 45 procent av

\section{Den klassifikation av yrken som använts i} studien utgår från graden av kvalifikation i arbetetet och ställning i termer av inflytande över egen eller andras arbete Socioekonomisk indelning enligt Folk- och Bostadsräkningen. kvinnor på hög tjänstemannanivå att arbetet är stressigt. Bland männen är siffrorna omvända. Det är således fler manliga tjänstemän på hög nivå än på mellannivå som upplever stress $i$ arbetet.

Stress är ett särskilt stort problem för tjänstemän på hög- och mellannivå medan tunga, monotona och smutsiga jobb är ett arbetarproblem. T.ex. uppger nästan hälften av de varuproducerande männen att de har fysiskt tunga arbeten. Motsvarande gäller för 38 procent av de tjänsteproducerande. Av kvinnor i servicearbete upplevde 35 procent stress och bland manliga produktionsanställda 43 procent. Upplevelse av stress i arbetet är således ett stort problem också för arbetare och särskilt för arbetare i varuproduktion.

De kvinnor som upplever sig ha betungande arbetsvillkor arbetar heltid i något högre utsträckning än de övriga kvinnorna, men skillnaderna i arbetstid mellan grupperna är inte särskilt stor. Det förefaller alltså inte som om arbetstiden har något avgörande inflytande på hur kvinnorna uppfattar sina arbetsvillkor. Männen i urvalet arbetar nästan uteslutande heltid, varför de inte kan jämföras med kvinnorna i detta avseende.

\section{Arbetsvillkor och välbefinnande/ psykisk hälsa}

Hur upplever kvinnor och män sitt allmänna tillstånd av psykisk hälsa? Enligt det mått som använts i studien kan vi konstatera att närmare hälften av männen och drygt en fjärdedel av kvinnorna anser att deras psykiska hälsa är god. ${ }^{5}$ Endast 7 procent av männen och 18 procent av kvinnorna bedömer sin psykiska hälsa som dålig. 


\section{Tabell 2}

Subjektiv värdering av välbefinnande/ psykisk hälsa bland kvinnor och män. Procentandelar.

\begin{tabular}{lrr} 
& Män & Kvinnor \\
\cline { 2 - 3 } God psykisk hälsa & 48 & 27 \\
Medelgod psykisk hälsa & 45 & 55 \\
Dålig psykisk hälsa & 7 & 18 \\
\hline Totalt & 100 & 100 \\
N & 215 & 455
\end{tabular}

Dessa skillnader mellan könen är likartad inom alla klasser. Dvs., trots att män och kvinnor totalt sett i undersökningen bedömer sina arbetsvillkor som likartade har kvinnor sämre välbefinnande än mạnnen.

I denna studie finns ett visst samband mellan välbefinnande och arbetsvillkor. Bland kvinnor med betungande jobb har 24 procent dålig psykisk hälsa mot 13 procent av dem som inte har betungande jobb. För män finns en liknande tendens, men svagare. Resultaten visar således att det finns en interaktion mellan arbetsvillkor och psykisk hälsa.

Arbetstid visar emellertid inga påtagliga samband med kvinnornas eller männens psykiska hälsa i denna undersökning.

Vi kan således konstatera att:

- Inom samma yrkesgrupper bedömer kvinnor och män sina arbetsvillkor som likartad

5 Välbefinnande/hälsa har mätts som ett summerat index utifrån följande fråga: »Hur skulle du vilja bedöma ditt hälsotillstånd f.n. (de senaste två veckorna) med avseende på nedanstående faktorer? Trött; Stressad; Värk, t.ex. rygg, huvud, nacke; Förkyld; Nedstämd; Känsla av otillräcklighet.
- arbetstiden har liten betydelse för denna bedömning bland kvinnor

- kvinnor bedömer sin psykiska hälsa som sämre än män

- arbetsvillkoren bedömda som betungande eller icke betungande har ett visst inflytande på hur man bedömer sitt välbefinnande. Bland kvinnor är detta tydligare än bland män.

- arbetstid har inget inflytande på hur kvinnor och män bedömer sitt psykiska välbefinnande.

\section{Välbefinnande och familjesituation}

\section{När man kommer hem frain jobbet}

Mödrarna och fäderna har i undersökningen besvarat en fråga om hur de känner sig när de kommer hem från sitt arbete. ${ }^{6} \mathrm{Av}$ svaren framgår att kvinnor i något större utsträckning än män mår sämre vid hemkomsten (Kvinnor 20 procent negativa, män 16 procent). Detta gäller för samtliga indikatorer inom måttet (se not 5).

Jämförelser mellan kvinnor och män i olika yrkesgrupper visar att bland de högt kvalificerade yrkesgrupperna, känner sig dubbelt så många kvinnor som män stressade, trötta osv. Bland de andra yrkesgrupperna är skillnaderna mellan könen obetydliga. Resultaten visar överensstämmelse med en undersökning av kvinnliga och man-

6 Frågans formulering: »Hur har du känt dig den senaste tiden, t.ex. de senaste två veckorna, när du har kommit hem från jobbet? Svara med en skala 1-5; Avslappnad-Stressad; PiggTrött; Glad-Nedstämd; FörväntansfullUtled.» 
liga chefstjänstemän, som visade att kvinnornas stressnivå ökade vid femtiden på eftermiddagen medan männens sjönk (Frankenheuser, 1991). Kvinnornas ökade stress tolkades som ett resultat av att de efter arbetsdagens slut gick på ett nytt skift, dvs. arbetet med att hämta barn, laga middag, ordna och planera för familjen. Min tolkning av resultaten är att stressnivån hos kvinnorna troligtvis också beror på att de känner otillfredsställelse med att inte hinna med jobbet. Det framgick i föregående avsnitt att både män och kvinnor i detta skikt upplever sig vara mycket stressade - män mer än kvinnor. Det framgår vidare av resultaten att inom detta skikt män har mer övertid än kvinnor. Det kan vara så att, även om män anser sig vara mer stressade på jobbet, kan de ändå tillåta sig att avsluta sitt arbete innan de måste gå hem och alltså känna sig mer avspända och förväntansfulla när de åker hem. Kvinnor måste rusa iväg med oavslutat jobb och med pappren i portföljen - jobb som måste avslutas någon gång när alla andra krav där hemma har lagt sig.

Resultaten visar att för män i allmänhet har arbetsbelastningen $\mathrm{i}$ jobbet ingen signifikant betydelse för hur de känner sig när de kommer hem från jobbet, medan det för kvinnor har en stor betydelse. ${ }^{7}$ Däremot visar sig arbetstid inte ha någon betydelse för hur kvinnorna känner sig när de kommer hem från jobbet.

7 Skillnaden mellan kvinnor med resp. utan betungande arbeten är signifikant på femprocentsnivån med chi- 2 test. 30 procent av de med betungande arbetssituation mot 13 procent av dem utan betungande arbetssituation känner sig negativa då de kommer hem från jobbet.
Man kan förmoda att arbetsbelastningen i hemmet har betydelse för hur man upplever sin hemkomst. T.ex. torde antalet barn hemma vara en viktig faktor. Det visar sig dock att antalet barn har en oväntad effekt. Ju fler barn att ta hand om desto färre känner sig negativa - både bland kvinnor och män.

Däremot visar det sig att kvinnor som upplever arbetet med hushåll och barn som betungande (se nedan) i signifikant högre grad än de som upplever det som lätt känner sig negativa när de kommer hem från jobbet. ${ }^{8}$

Resultaten visar också att de som lever i familjer med många konflikter (se not 1) upplever sig negativa vid hemkomst. Detta gäller särskilt för kvinnor, men tendensen för männen är likartad. ${ }^{9}$

\section{Upplevelse av hemarbetet}

I min undersökning gjordes ingen mätning av arbetsfördelningen mellan män och kvinnor. SCB har dock nästan samtidigt gjort en detaljerad studie av detta (Rydenstam, 1993). En bearbetning av SCB:s data om småbarnsföräldrar med olika arbetsintensitet visar att i familjer där båda makar arbetar heltid ägnar män 7 timmar per vecka och kvinnor 15 timmar åt barnomsorg. Hushållsarbete ägnar män 6 timmar och kvinnor drygt 16 timmar. Total tid för hemarbete är 22 timmar för män och 40 timmar för kvinnor. När man tar hänsyn till alla typer av hemarbeten ökar bådas tid men den sneda fördelningen kvarstår.

8 Skillnaderna är signifikanta på femprocentnivån med chi-2 test, för kvinnor. Bland männen är det för få som upplever hushållsarbetet som betungande.

9 Skillnaderna är signifikanta på femprocentsnivån med chi-tvåtest, både för kvinnor och för män. 
Denna sneda arbetsfördelning är känd sedan länge och har således åter bekräftats i en undersökning från början av 90-talet. En förklaring som ofta förs fram i diskussionerna om denna arbetsfördelning är att kvinnor inte vill släppa till, de agerar grindvakt och slår vakt om sitt revir. Kvinnor lever i livsformer som alla är präglade av en grundläggande husmorsideologi - oavsett om de förvärvsarbetar eller inte (Friberg, 1990; Karlsson och Jacobsen, 1993; Rahbeck, 1987)

Samtidigt kan vi konstatera att kvinnors livsformer i Sverige förändras allt mer i riktning mot lönarbetets livsformer. Av båda könen anser 90 procent att den officiella värderingen av hemarbetet är mycket låg. Detta är för övrigt ett internationellt fenomen (Hall, 1990).

Mot denna bakgrund kan man anta att arbete och ansvar för hem och barn blir en ökad källa till konflikt mellan makarna och att själva känslan för hemarbetet blir mer negativ - oavsett hur tung arbetsbördan i praktiken är.

I undersökningen har intervjupersonerna fått frågan hur de uppfattar ansvaret för arbetet med hem och barn. Olika uppgifter rörande barn och hushåll listades. ${ }^{10}$ Ett summationsindex visar att endast en minoritet av männen - 7 procent - upplever hushållsarbetet som betungande, vilket är fallet för 22 procent av kvinnorna. ${ }^{11}$

En detaljerad beskrivning av hur hushålls-

\footnotetext{
10 Frågans formulering: Om du tänker på de senaste två veckorna, tycker du då att din del av ansvaret för familjen har känts lätt eller jobbig för dig?

11 Skillnaden mellan könen är signifikant på femprocentsnivån med chi-två test.
}

arbetet upplevs redovisas i diagram 1 (se s. 122). Skillnaderna mellan kvinnor och män är betydande på varje moment i hemarbetet, utom för underhåll och reparation där fler män än kvinnor ( 22 procent mot 14 procent) upplever arbetet som betungande.

Könsskillnaderna består även vid jämförelserna mellan yrkesgrupper. Genomgående är det fler kvinnor bland de kvalificerade yrkesgrupperna som upplever hushållsarbetet som ansträngande.

Upplevelsen av hemarbetet som betungande påverkas inte av antalet barn, varken för kvinnor eller män. Det påverkas inte heller av om man har betungande arbetsvillkor eller av arbetstidens längd.

Bland de kvinnor som lever i konfliktbenägna familjer är det signifikant fler som upplever hemarbetet som jobbigt - 39 procent- jämfört med 17 procent av de som lever i icke-konfliktfamilj. Bland männen är motsvarande siffror 13 procent resp. 5 procent. Det är således också något fler män som upplever hemarbetet som betungande när de lever i konfliktfamiljer men i jämförelsen med kvinnorna är männen tämligen litet påverkade (Se diagram 2, s. 26.)

\section{Balansen mellan arbete och familj}

Ytterligare en indikator på förhållandet mellan förvärvsarbete och familj som användes i studien är hur man uppfattar att man klarar balansen mellan arbete och familj. ${ }^{12}$

\footnotetext{
12 Frågans formulering: Tycker du att du lyckas förena förvärvsarbete och familjeliv? Lyckas inte alls bra; Lyckas sällan så bra; Lyckas ibland; Lyckas bra;Lyckas mycket bra (5-gradig skala) Lyckas mindre bra $=1-3$
} 


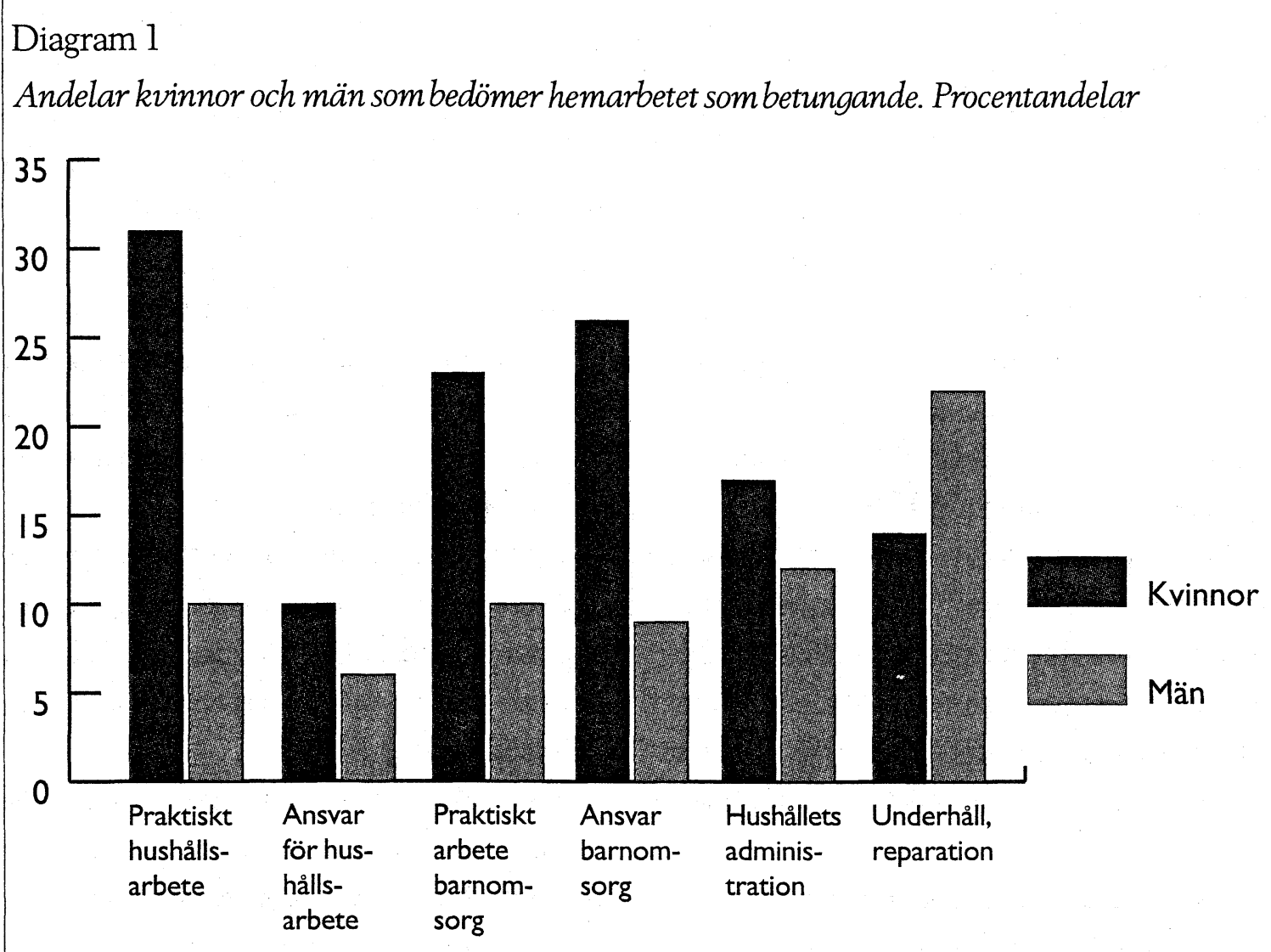

\section{Diagram 2}

Andelar kvinnor och män som upplever hemarbetet sombetungande efter om man lever ifamiljer med många respektive få konflikter. Procentandelar

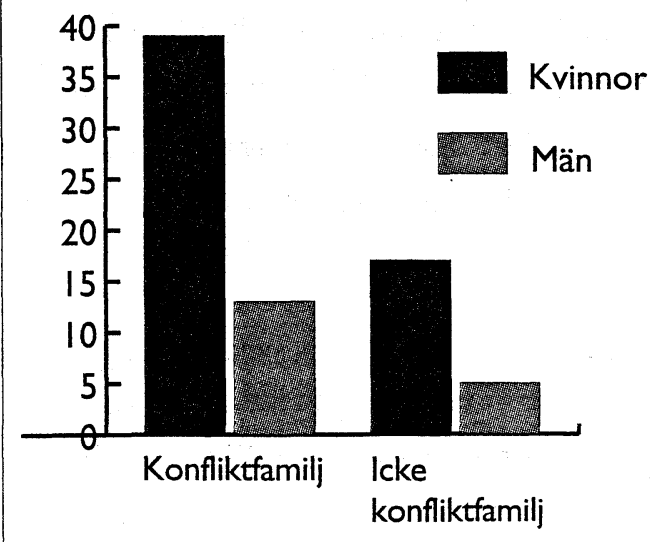

Kvinnor i allmänhet visar mindre tilltro till sin förmåga att balansera arbete och familj. Särskilt gäller detta kvinnor och män i de kvalificerade yrkesgrupperna (högre tjänstemän), där tilltron är lägst bland båda könen. Manliga tjänstemän på mellan nivå har störst tilltro bland männen (Se tabell 3).

Bland båda könen har både arbetsvillkor och arbetstid betydelse för upplevelsen av hur man lyckas balansera arbete och familj och arbetsvillkor samt arbetstid. Dessa faktorer förefaller dock ha större betydelse för kvinnor än för män. Dock kan konstateras att hela 43 procent av de män som arbetar mer än heltid anser att de lyckas mindre bra.

Att ha ett eller två barn tycks inte spela så stor roll för varken kvinnor eller män, men med tre barn ökar upplevelsen av att lyckas 


\section{Tabell 3}

Bedömning av hur balansen mellan arbete och familj lyckas bland kvinnor och män efter klasstillhörighet. Procentandelar

\begin{tabular}{|c|c|c|c|c|c|c|c|c|}
\hline & \multicolumn{2}{|c|}{ Arbetare } & \multicolumn{2}{|c|}{ Tjänstemän } & \multicolumn{2}{|c|}{ Högre tjänstemän } & \multicolumn{2}{|c|}{ Totalt } \\
\hline & män & kvinnor & män & kvinnor & män & kvinnor & män & kvinnor \\
\hline $\begin{array}{l}\text { Lyckas } \\
\text { mindre bra }\end{array}$ & 16 & 25 & 15 & 26 & 42 & 35 & 21 & 27 \\
\hline$N$ & 35 & 158 & 119 & 240 & 50 & 45 & 215 & 455 \\
\hline
\end{tabular}

mindre bra med balansen arbete och familj både bland kvinnor och män.

Att leva i en familj med många konflikter ger ett dåligt odds för hur man tycker att man lyckas balansera arbete och familj - särskilt bland männen. 47 procent av männen i konfliktfamilj lyckas mindre bra mot 16 procent av dem som lever i icke konfliktfamilj. Bland kvinnorna är motsvarande siffror 32 procent resp. 20 procent.

Vem drabbas då främst av att balansen inte lyckas? Både bland kvinnor och män är det relativt få som anser att arbetet eller kollegorna blir lidande. I främsta hand bedömer kvinnorna att det är de själva som drabbas (Se tabell 4).

Jämförelsen totalt mellan kvinnor och män visar att båda könen i första hand anser sig själva vara drabbade av problemet med att klara balansen mellan arbete och familj mindre väl. En intressant skillnad är att män i betydligt högre omfattning än kvinnor anser att frun eller sambon drabbas medan kvinnorna $i$ högre utsträckning än männen anser sig

Tabell 4

Vem drabbas av bristande balans mellan arbete och familj. Jämförelser mellan kvinnor och män iolika yrkesgrupper. Procentandelar

\begin{tabular}{|c|c|c|c|c|c|c|c|c|}
\hline & \multicolumn{2}{|c|}{ Arbetare } & \multicolumn{2}{|c|}{ Tjänstemän } & \multicolumn{2}{|c|}{ Högre tjänstemän } & \multicolumn{2}{|c|}{ Totalt } \\
\hline & män & kvinnor & män & kvinnor & & kvinnor & män & kvinnor \\
\hline $\begin{array}{l}\text { Instämmer } \\
\text { helt }\end{array}$ & & & & & & & & \\
\hline $\begin{array}{l}\text { Mina barn } \\
\text { Mina }\end{array}$ & 27 & 32 & 25 & 24 & 24 & 25 & 26 & 27 \\
\hline kollegor & - & 8 & 13 & 10 & - & 13 & 2 & 7 \\
\hline Mitt arbete & 9 & 8 & 25 & 17 & 10 & 13 & 13 & 12 \\
\hline Jag själv & 45 & 32 & 50 & 59 & 24 & 50 & 36 & 48 \\
\hline Min partner & 9 & - & 13 & 12 & 38 & 11 & 26 & $\varepsilon$ \\
\hline$N$ & 11 & 53 & 16 & 63 & 21 & 16 & 47 & 122 \\
\hline
\end{tabular}


själva vara drabbade. Jämförelsen mellan klasser visar att det särskilt är tjänstemännen som ser sig själva som drabbade. I denna grupp anser också männen att deras arbete kommer i kläm.

Sammanfattningsvis visar resultaten att

- kvinnor mår sämre än män när de kommer hem från jobbet. Detta gäller alla yrkeskategorier.

- kvinnor upplever hemarbetet som betungande i väsentligt högre omfattning än män

- Fler kvinnor än män anser att de klarar balansen mellan arbete och familj mindre väl.

- Det är främst man själv som drabbas när balansen lyckas mindre bra. Därnäst kommer barnen, enligt föräldrarnas egen bedömning.

- Bedömningen av arbetsvillkoren som betungande påverkar hur kvinnor känner sig när de kommer hem från jobbet $\mathrm{i}$ negativ riktning. Arbetstid påverkar dock inte känsla vid hemkomst.

- Däremot påverkar varken arbetsvillkor eller arbetstid om man upplever hushållsarbetet som betungande eller ej. Arbetsvillkor och arbetstid inverkar också på hur kvinnor anser att balansen arbete och familj fungerar.

- För männen har varken deras arbetsvillkor eller deras arbetstid någon inverkan på bedömningen av hur de känner sig när de kommer hem från jobbet eller hur de upplever sin del i hemarbetet. Däremot har arbetsvillkor och arbetstid viss betydelse vid männens bedömning av hur väl de lyckas balansera arbete och familj.

- Antalet barn tycks inte spela särskilt av- görande roll för upplevelserna av hemarbetet och hur man känner sig när man kommer hem från jobbet. Varken för kvinnor eller män. Känslan av att kunna balansera arbete och familj påverkas negativt hos dem som har tre barn eller fler.

Resultaten tyder på att upplevelsen av att balansera arbete och familj har med lönarbete snarare än med hemarbetet att göra.

\section{Konflikter i familjen, välbefinnande och hemansvar}

Resultaten i denna studie visar att konflikter i familjen (se not 1) för hur måttet har konstruerats) är en mycket betydelsefull faktor i samband med samtliga variabler som här har studerats - upplevelse av hemarbetet som betungande eller inte, upplevelsen av att balansera arbete och familj samt hur man mår när man kommer hem från jobbet. Konflikter i familjen visar också samband med välbefinnande (psykisk hälsa). Av de kvinnor som lever i familjer som klassificerats som konfliktbenägna har 23 procent sämre välbefinnande jämfört med 12 procent av de som lever i familjer med liten konfliktbenägenhet. Bland männen har 18 procent i konfliktfamilj dålig psykisk hälsa mot 4 procent i icke-konfliktfamilj (Se diagram 3). Mer än dubbelt så många kvinnor i konfliktfamiljer upplever hemarbetet som betungande

Föräldrarnas arbetsvillkor eller deras arbetstider visar dock inte något paitagligt samband med graden av konflikter i familjen.

Siffrorna visar att kvinnornas sämre välbefinnande jämfört med männens kvarstår vare sig de lever i familjer med många konflikter eller ej. Det tyder på att kvinnor påverkas negativt mer än män av att leva i konflikt- 


\section{Diagram 3}

Bedömning av psykisk hälsa. Kvinnor och män efter om de lever i famij med många respektive få konflikter. Procentandelar

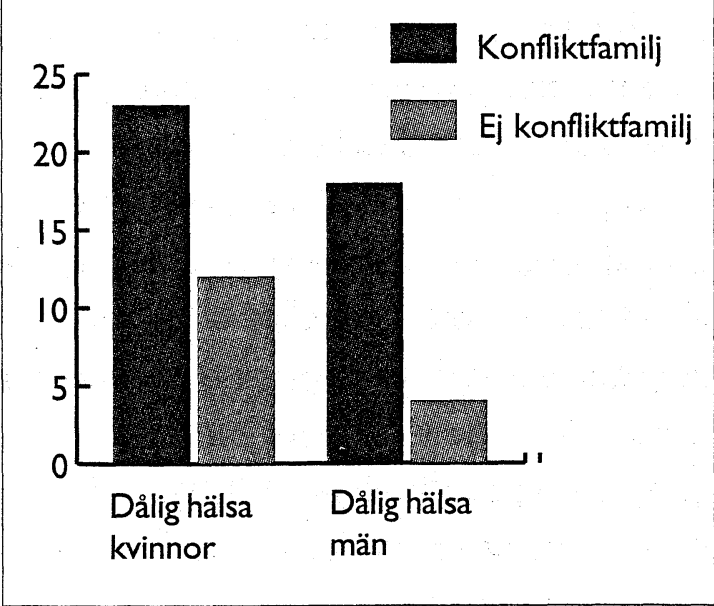

laddade familjer. De upplever också att de har konflikter mer än män.

Studiens resultat visar också att välbefinnande eller psykisk hälsa är en betydelsefull faktor i samband med hur man upplever hemansvar och möjligheten att förena förvärvsarbete och familjeliv. Som exempel kan nämnas att 42 procent av de kvinnor som uppger sig ha dålig psykisk hälsa upplever hushållsarbetet som betungande mot endast 11 procent av de som har god psykisk hälsa. Detta resultat är kanske inte så märkvärdigt. Om man mår dåligt tenderar man också att uppleva arbete som betungande, man tenderar att misstro sin förmåga att balansera arbete och familj och man känner sig ur form när man kommer hem från jobbet.

Sammanfattningsvis ger resultaten i studien en indikation på att familjesituationen är en betydelsefull faktor när det gäller hur förvärvsarbetande småbarnsföräldrar upplever arbetet i hemmet, förvärvsarbetet och psykisk hälsa. Resultaten tyder på att kon- kreta stressfaktorer i familjelivet, särskilt uttryckt som graden av konflikter i familjen är en dold faktor i förståelsen av psykisk hälsa och välbefinnande för både mödrar och fäder. Såtillvida stöder studiens resultat hypotesen att kvinnors försämrade psykisk hälsa måste analyseras som en kombinerad effekt av arbetsvillkor och familjesituation. Upplevelsen av familjeansvar och individuellt välbefinnande är en följd av hur man har det på jobbet och hur man har det $\mathrm{i}$ hemmet.

\section{Avslutande diskussion}

I likhet med tidigare refererade studier visar resultaten från denna studie att kvinnors psykiska välbefinnande är sämre än männens. Resultaten visar också att det finns en interaktion mellan arbetsvillkor och psykiskt välbefinnande resp upplevelse av hemansvar, särskilt för kvinnor. Deras psykiska hälsa påverkas negativt av betungande arbetsvillkor och av att uppleva ansvaret $i$ hemmet som betungande. Arbetstiden i lönarbete spelar en viss roll men kanske mindre än väntat. Hemsituationen och särskilt upplevelsen av konflikter i familjen förefaller vara en väl så betydelsefull faktor i samband med uppkomst av psykisk ohälsa.

Varför leder ansvar för hem och familj till psykisk ohälsa bland kvinnor? När vi skall försöka förstå varför ansvaret för och arbetet med hem och familj leder till psykisk ohälsa bland kvinnor uppfattar jag det som nödvändigt att beakta ett flertal olika förhållanden. Dels handlar det om att hemarbetet i sig både innehåller moment av tillfredsställelse men också av stress i form av t ex känsla av otillräcklighet. Vad som också är viktigt att beakta är kvinnors relativt låga makt i familj och 
samhälle jämfört med männens.Vi måste också beakta hemarbetets låga värdering $i$ offentligheten och de kulturkonflikter som detta ger upphov till i kvinnors livsformer. Det är också viktigt att se till vad familj betyder för kvinnor och män i det moderna samhället.

Hemmet som arbetsplats kan inte jämställas med en vanlig arbetsorganisation inom lönarbetets sfär. Makthierarkier och incitament skiljer sig mellan hemmet och arbetsplatsen. I familjen finns en gåvoetik som sällan förekommer $i$ en arbetsorganisation (Kauffmann, 1992). Men i hemarbetet finns dimensioner som kan jämställas med de i lönarbetet. I sin teoretiska modell över stress i lönarbete identifierar Karasek två dimensioner - psykologiska krav i arbetet och graden av kontroll eller beslutsutrymme i arbetet. Stor psykologisk press men liten kontroll över arbetet anses ge upphov till negativ stress. Hög psykologisk press i kombination med stort beslutsutrymme anses ge upphov till positiv stress (Karasek \& Theorell, 1990). Dessa dimensioner kan också användas i en analys av hemarbete. I hemarbetet kombineras ansvar för familjens välbefinnande med mängden arbete och med kontroll över arbetet. Eftersom kvinnor har nästan allt ansvar och gör det mesta av arbetet bör, enligt modellen, detta ge upphov till positiv stress och inte psykisk ohälsa hos kvinnorna. Lundberg har emellertid i sin studie visat att graden av ansvar för hemarbetet (och mängden arbete) med statistisk prövning visat att detta stora ansvar bidrar till ökad ohälsa bland kvinnor. Min studie pekar i liknande riktning. I hemmet har kvinnor stort ansvar men liten makt att delegera arbetsuppgifter och kontrollen över arbetet är också begränsad i praktiken, vilket sammanhänger med hushållsarbetets och omsorgens karaktär. T.ex., när huset är städat kommer barnen in med kompisar och leriga stövlar. När mjölken står på spisen, ringer telefonen och spädbarnet skriker, mjölken kokar över etc. Exemplen kan mångfaldigas, men poängen är att villkoren för arbetet ställs av andra än kvinnan själv.

Kvinnor i alla samhällsklasser har en grundläggande husmorsideologi, vare sig de också har ett lönarbete eller inte. Föreställningarna om vad som ligger i detta varierar inom olika samhällsklasser, men vad som tycks vara grundläggande i de flesta fall är att husmorsideologin definieras utifrån mannens arbete och låter sig styras av mannens villkor. Det handlar med andra ord om att kvinnor anpassar sitt arbete efter mannens arbete (Karlsson och Jacobsen, 1993; Finch, 1983).

I takt med att lönarbetet har blivit en självklarhet för både kvinnor och män sker en successiv omdefiniering av kvinnors livsformer. Med försörjarrollen följer också för kvinnor en identitet som lönarbetare liknande den som männen har. I männens livsformer intar försörjarrollen och försörjningsarbetet en central plats. ${ }^{13}$ Försörjning ger rätt till fritid. Fritid innebär emellertid olika saker för kvinnor och män. För kvinnor är fritiden starkt sammankopplad med bilden av familjen som ett gemensamt projekt. Detta är emellertid inte det samma som att vara husmor. Hemarbetet är för kvinnor inte fritid, men män uppfattar ofta hemarbete som fri-

13 För en redovisning av innebörden av livsformsbegrepp hänvisas till Rahbeck, 1987; Björnberg och Bäck-Wiklund, 1990; Friberg, 1990; Karlsson och Jacobsen, 1993. 
tidssyssla, något som man gör när man har lust. För kvinnor blir detta att själva bära ansvaret för hem och familj en motsättningsfull och konfliktskapande erfarenhet. Kanske är det inte så mycket de enskilda arbetsuppgifterna i sig som skapar stress och trötthet, utan känslan av att ensam bära ansvaret för familjemedlemmarnas väl och ve. Ansvaret är t.o.m. mindre synligt än själva hushållsarbetet och tillerkänns ofta inte något erkännande. Omsorg kräver tid och engagemang. Hushållsarbete kräver tid och kraft. I valet mellan vad som skall göras väljer kvinnor ofta att skära ned på hushållsarbetet, men ansvaret för det är svårt att komma undan. Prioriteringarna är i sig konfliktskapande. Känslan av bristande balans mellan förvärvsarbete och familj är en konflikt. Resultaten från denna undersökning visar att kvinnor i hög utsträckning anser att bristen på balans mellan arbete och familj drabbar dem själva i första hand.

I sin bok Brave new families beskriver Judit Stacey (1990) post-modernt familjeliv, dvs. familjeformer som under 1970-90-talet vuxit fram i USA (och i övriga delar av de västliga industriländerna). Postmoderna familjer är, enligt Stacey, både otrygga och odemokratiska i förhållande till de ideal som feminister och andra förespråkare för familjens förändring hade. Enligt idealen skulle moderna familjer ha en könsordning byggd på lika värde för män och kvinnor, kamratskap, jämställt partnerskap och föräldraskap. Om inte ekonomiskt oberoende så ändå ekonomiskt beroende byggt på symmetri och inte på kvinnors underordning.

Dessa ideal omfattas teoretiskt av de flesta män och kvinnor i dagens samhälle. Idealen tillämpas dock inte i praktiken. De postmoderna familjerna växte fram samtidigt som de moderna industrisamhällena gick in en lång period av ekonomiska kriser och stagnerande tillväxt. De sociala klyftorna i samhället har vidgats genom omfattande omfördelningar, skattesänkningar och neddragningar i offentlig service. Kvinnorna har med ökat lönarbete bidragit till att stötta upp hushållens ekonomi. En lön - mannens lön - räcker inte längre för att försörja en familj.

Kvinnorna har i stor omfattning trätt ut i ett arbetsliv skapat för män och med förutsättningen att det finns en hemmavarande kvinna som sköter markservicen. Män har inte tagit motsvarande steg in i familjen och engagerat sig i det lågt värderade hushållsarbetet. I stället för det jämlika partnerskapet bygger den postmoderna familjens realiteter på en könsordning fri från normer över huvud taget, menar Stacey. Allt är förhandlingsbart - föräldraskapet, sexualiteten, arbetsfördelningen, resursfördelningen. Denna situation leder till omfattande otrygghet och konflikter - på ojämlika villkor. Det blir en kamp inom familjen snarare än en förnuftig förhandling (Stacey, 1990).

Utvecklingen i Sverige under motsvarande period har inte varit så brutal som i USA. I jämförelse med situationen i USA har kvinnorna haft tillgång till betydligt mer och bättre social service i form av omsorg om barn och gamla. Samtidigt kan vi konstatera att liknande tendenser finns också hos oss. Kvinnor har under 80-talet blivit relativa förlorare. Deras löner relativt männens har minskat. Arbetsvillkoren, särskilt de psykiska har försämrats för kvinnor.

De arbetar mer utanför hemmet, men hemarbetet delas i liten utsträckning. I stället 
för att dela arbetet med männen har kvinnorna skurit ned på hushållsarbetet.

Den ojämna arbetsfördelningen $\mathrm{i}$ hemmet bidrar till psykisk ohälsa hos kvinnor. Även om resultaten i min undersökning ännu så länge kan ses som tentativa visar de på behovet av fördjupade analyser av konflikters och andra stressfaktorers roll inom familjelivet i samband med ohälsa hos kvinnor och män. Konflikter är en viktig dimension i förståelsen av dagens familjeliv och konfliktdimensionen $i$ detta har många aspekter.

\section{Referenser}

Björnberg, Ulla och Bäck.-Wiklund, Margareta (1990) Vardagslivets organisering i familj och närsamhälle. Göteborg: Daidalos

Björnberg, Ulla red. (1992) European Parents in the 1990s. Contradictions and Comparisons. New Brunswick: Transaction

Frankenheuser, Marianne (1991) "The psychophysiology of sex differences as related to occupational status i i Frankenheuser, M.,Lundberg, O., Chesney, M. Red. Women, work and health. Stress and opportunities. New York: Plenum Press

Friberg, Tora (1990) Kvinnors vardag. Om kvinnors arbete och liv. Anpassningsstrategier $i$ tid och rum. Lund: Lund University Press

Fritzell, Johan och Lundberg, Olle (1994) Ett förlorat eller förlovat årtionde? Välfärdsutvecklingen mellan 1981 och 1991. Stockholm: Institutet för Social Forskning Giddens, Anthony (1992) The transformation of intimacy. Sexuality, love and eroticism in modern societies. Cambridge: Polity Press

Hall, Ellen (1990) Women's Work: An Inquiry into the Health Effects of Invisible and Visible Labor. Stockholm: Karoliska Institutet

Karasek, Robert och Theorell, Töres (1990) Healthy Work. Stress, Productivity And The Reconstruction OfWorking Life. New York. Basic Books, Inc., Publishers

Karlsson, Jan och Jacobsen, Liselott (1993) Arbete och kärlek. En utveckling av livsformsanalys. Lund: Arkiv Förlag

Kauffmann, Jean-Claude (1992) La trame conjugale. Analyse du couple par son linge. Paris: Éditions Nathan
Koch-Nielsen, Inger m fl (1987) Skilsmisser. Köpenhamn: Socialforskningsinstituttet publikation 118

Lundberg, Olle (1990) Den ojämlika ohälsan. Om klass- och könsskillnader $i$ sjuklighet. Stockholm: Institutet för Social Forskning

Moen, Phyllis (1989) Working Parents. Madison Wiscounsin: The University of Wiscounsing Press

Rahbeck, Lone (1987) Hver vore veje. Odense: Etnologisk Forum

Rydenstam, Lars (1993) I tid och otid. Om kvinnors och mäns tidsanvändning 1990/ 1991. Rapport 79 Levnadsförhållanden. Stockholm: SCB

Socioekonomisk indelning (SEI). Meddelanden $\mathrm{i}$ samordningsfrågor 1982:4. Stockholm: SCB

Stacey, Judit (1990) Brave New Families. Stories of Domestic Upheaval in Late Twentieth Century America. New York: Basic Books

Sundström, Marianne (1993) "The Growth in Full Time Work Among Swedish Women in the 1980su i Acta Sociologica 36: 2, 139-150

Szulkin. Ryszard och Tåhlin, Michael (1994) "Arbetets Utveckling" i Fritzell, J., Lundberg, o., Red. Vardagens Villkor. Levnadsförhällanden i Sverige under tre decennier. Stockholm: Brombergs

Wadsby, Marie och Svedin, Carl Göran (1993) "Skilsmässa - bakgrund, orsaker och följder" i Agell, A., Arve-Parès, B., Björnberg, U., Red. Om Modernt Familjeliv och Familjeseparationer. Stockholm: Socialvetenskapliga Forskningsrådet 


\section{Summary}

\section{How is mental health influenced by work and family life?}

This article deals with gender differences in psychological well-being. A point of departure for the problem dealt with is that women to a much higher extent than men report psychological illness. Women also tend to initiate divorce to a higher extent than men.

In the article preliminary results on psychological health are presented in relation to conditions in paid work, household responsibilities and family situation in terms of number of children and experienced rate of conflicts in the family.

The data are based on interviews with 670 employed parents with children under the age of five.

The results, which at this stage can be considered as being a qualitative analysis based on quantitative data, point to an inter- action between conditions in paid work and experience of home responsibilities in explaining psychological well being among women. This interaction seems to be weaker among men. Hard working conditions and working time are of less importance for whether household labour is experienced as hard or easy. But these factors influence the feelings of having a proper balance between family and job and how people feel on coming home from the job.

For women and for men, the number of children seems to be of minor importance for judgement of psychological health and experience of household responsibilities. Experienced rate of conflicts in the family seems to be an important predictor of psychological well-being, especially for women. 